\title{
A.JOTE
}

African Journal of Teacher Education

ISSN 1916-7822. A Journal of Spread Corporation

Volume 10. No. 12021 Pages 365-391

\section{Students' Perspectives on Satisfaction with Distance Education in Ghana: A Cluster Analysis}

\author{
Francis Owusu Mensah ${ }^{1}$, Kingsley Agyapong ${ }^{2}$, \\ \& Augustine Acheampong ${ }^{3}$ \\ ${ }^{1}$ Institute for Distance and e-Learning, University of Education, Winneba, Ghana. \\ ${ }^{2,3}$ Dept of Management Studies Education, Akenten Appiah-Menka University of Skills Training and \\ Entrepreneurial Development, Kumasi, Ghana
}

\begin{abstract}
This study sought to categorise students based on the preferences that influenced their choice of distance education program in Ghana. Questionnaires were used to collect data from 120 students taking part in the University of Education, Winneba (UEW) distance education (DE) programme at the Kumasi Girls Senior High School [SHS] Study Center. Respondents were segmented into three clusters (highly, moderately, and least satisfied) based on four preferences (price, quality, packaging, and social boding) that influenced their satisfaction with the distance education programme. Results from both hierarchical and non-hierarchical cluster analysis with squared Euclidean distance and Ward's method showed that the highly satisfied cluster was driven by the quality of service and the competitive fees structure of the UEW distance education programme. Further analysis of the differences between the clusters indicated that satisfaction with the UEW distance programme significantly differs across the three segments.
\end{abstract}

Keywords: Distance education, price, quality, packaging, social bonding, Ghana

\section{Introduction}

The Report of the President's Committee on Review of Education Reforms in Ghana (2002) mandated Universities to embark on educational reforms at all levels to make education respond to Ghana's national industrial and technological developmental and high level skills training needs for all sectors of the nation's economy. The Committee's report acknowledged the need for Ghana to vigorously pursue a national programme in distance education. It recommended the use of distance education as an alternative to conventional education and called for government support 
for tertiary institutions offering distance education. Manu and Agyapong's (2014) study on the prospects of providing distance education programmes for professional teachers in Ghana supports the view that distance education is an effective alternative to conventional education as it enables professional teachers to combine their professional work with further professional studies. Distance education is an effective way to provide university education to thousands of qualified applicants. Sujatha (2002) posits that distance education enables interested over-aged persons to obtain relevant education. Hence, distance education consists of a diverse cluster of students with different characteristics and this diversity calls for different marketing strategies. To successfully match their products and services to their students' needs, distance education planners must make decisions on which students should be targeted and which programmes should be offered. Engaging in these decision-making processes makes segmentation one of the fundamental activities that distance education planners engage in.

Considerable amount of research has been conducted in the area of distance education in Ghana, much of which has focused on technology and infrastructure (Ozdemir \& Abrevaya, 2007; Viberg \& Grönlundm 2015), course environment (Ahern \& El Hindi 2000; Faux \& Black-Hughes, 2000; Trinidad \& Pearson,2004), administrative and organisational issues (Dahl, 2003; Feist 2003; Vallejo, 2001), and tutoring (Jelfs, Richardson \& Price, 2009). However, there is limited research on student DE preferences and on how DE institutions design programmes specifically targeted at increasingly diverse segments of students. The purpose of this study is thus to address these gaps in the distance education literature. Accordingly, its research objectives are

1. To segment/cluster students taking part in the UEW distance education programme based on their satisfaction with the programme

2. To validate the student clusters/segments identified

3. To find out whether the factors that influence students' satisfaction with UEW distance education programmes differ across clusters

\section{Literature Review}

\subsection{The concept of distance education}

Perraton (1988:43) defines distance education 'as an educational process in which a significant proportion of the teaching is conducted by someone removed in space and/or time from the 
learner'. Keegan (1996) contends that distance education is a form of education with such attributes as:

- the quasi-permanent separation of teacher and learner throughout the period of the learning process (this distinguishes it from conventional face-to-face education)

- the influence of an educational organisation both in the planning and preparation of learning materials and the provision of student support services (this distinguishes it from private study and teach yourself programmes).

- the use of technical media-print, audio, video or computer - to unite teacher and learner and administer the content of the course.

- the provision of two-way communication so that the student may benefit from or even initiate dialogue (this distinguishes it from other uses of technology in education); and

- the quasi-permanent absence of the learning group throughout the length of the learning process so that people are usually taught as individuals rather than in groups, with the option of irregular seminars and meetings. (Keegan, 1996:50).

Distance education has been used in many countries to expand access to education for people who would otherwise not have had the opportunity to benefit from formal education (Perraton, 1988, 2004). This expansion has been made possible through print, radio, or television media (Perraton, 1998). Distance education's appeal lies in its potential to substitute or complement traditional teaching methods (Stewart, 1988). The need for continuous learning as well as the 'unprecedented innovation in communications' have facilitated the increased popularity of distance education (Garrison, 2000:1).

\subsubsection{Students' perception of courses}

Students' perception of the value of their courses and educational experience is inextricably connected to their sense of satisfaction. High satisfaction "leads to lower levels of attrition, greater learning success, and greater motivation" (Kuo et al., 2013).de Lourdes Machado et al., (2011) and Gibbons (2012) found the key to student satisfaction with their program to lay in teaching quality, interactions with faculty both in and out of class, and quality of academic advising and teaching assessment. One of the most repeated statements made by students concerning their satisfaction was the importance of faculty who came to class well prepared (Gibbons 2012). 


\subsection{Market segmentation}

Numerous marketing scholars have looked at the term market segmentation. Salami and Adewoye (2006) believe that when market segmentation is well undertaken, the result is the maximisation of returns on marketing expenditure. Market segments can be demographically classified based on the type of customer. Market segmentation consists of a group of customers who share a similar set of wants (Kotler, 2004). Market segments have present or potential customers with common features appropriate in explaining the customer's response to suppliers' market stimuli (Kotler, 2002). Market segment has further been described as a subgroup of people or organisations sharing one or more characteristics that cause them to have a similar product and/or service need (Kotler \& Keller, 2005). This presupposes that market segmentation is a homogeneous group of clients, each responding differently to advertising, delivery, pricing, and other marketing mix variables (Doyle, 2004). Segmentation and targeting are critical in the marketplace and allows the marketer to plan, develop and deliver a product or service that satisfies the needs and wants of the target market (Pickton \& Broderick, 2005). Kotler (2004) considers overall attractiveness and the company's objectives and resources as factors that affect segmentation looked at two factors when evaluating the market segment. Wood (2007) concludes that market segmentation is the process of grouping customers within a market according to similar needs, habits, or attitudes that can be addressed through marketing. Thus, splitting a market into different classes of consumers who have distinct interests, characteristics, or habits and may need different goods or marketing mixes (Armstrong \& Kotler, 2005). Thus, dividing the market, factors such as psychographic, demographic, geographic, psychological, and behavioural will enable the marketers to have a better understanding of the dynamics of the target market to help improve marketing effectiveness (Gunter \& Furnham, 1992).

\subsection{Factors influencing the patronage of product/service}

\section{- Price}

Price is the amount a customer is asked to pay for a product or the total of the values that consumers exchange for the benefits of having or using a product or service (Bearden et al 2004). Hinterhuber (2008) posits that pricing strategies differ in diverse ways across industries, countries, and customers. It means the price charged for different products or services has different names. For example, in the transport sector price is referred to as fare, it is referred to as a toll on drivers on 
the highway, rent to the tenants, a bill for water and electricity services to consumers, retainer to the lawyers and commission to the salesperson, etc. (Kotler et al., 2006).

The central role of price is to influence consumer buying behaviour, switching behaviour and satisfaction (e.g. Jakaria \& Gilbert, 2002; Keaveney, 1995; Matzler, Renzl, \& Faullant, 2007; Varki \& Colgate, 2001). Rondan (2004) suggests that price is an important factor in the purchase decision, especially for frequently purchased products. In describing the price, Kotler, Armstrong, Saunders and Wong (2002) maintain that it is the most significant factor that affects consumer's choice of goods and services, though other researchers indicate that price is the only variable among the four 'Ps' that produces revenue (e.g., Agwu \& Carter, 2014). Price has also been used as an indicator to separate luxury from non-luxury products (Al Khattab \& Aldehayyat, 2011). Dolnicar (2002) found that a higher price leads to the expectation of good service, a good location, a pleasant atmosphere, large rooms, and comfort in general, as well as the availability of the Internet in the service firms. Thus, customers use a higher price as an indicator of the quality of good or service (Kotler, 2009), to make judgments about product and service quality (Kotler \& Keller (2009), and that customers want good quality products/services at reasonable and affordable prices (Peng \& Wang, 2006; Wang, 2006). Therefore, customers perceive the price and quality of products/services to match but when price does not match the quality of products/services, customers experience dissonance (Oliver, 1997). In line with these studies, Agyapong, Acheampong, and Kwakye (2015) also found in their study that brand name, brand image, flexible payment terms, location, and worldwide acceptance of certificates by students are the factors that influence students' decisions in choosing a university for distance education.

The UEW is considered one of the affordable universities in Ghana in terms of its tuition fees. In addition, payment of tuition fees can be made in instalments, which makes paying it easier for students. According to Kotler and Keller (2009), many customers use price to make judgments about product and service quality, emphasizing that image pricing is effective with ego-sensitive products. Research for example by Joseph and Joseph (1997); Sia, (2013); Yusuf, Ghazali and Abdullah (2017) has established a relationship between price/cost on service quality and students' satisfaction. Price/cost has been suggested as one of the significant factors that students consider in making a choice among educational institutions. 


\section{Product/ Service quality}

According to Bitner et al., (1990), quality of service is a measure of customer satisfaction and Parasuraman et al. (1985) claim that quality of service is the degree of disparity between the expectations of customers for service and their real perceptions of service. Therefore, highly satisfied customers signify that the customer's actual performance is greater than their expectations (William, 2002). Kotler, Bowen, and Makens (1996) highlight a variety of views of quality based on product features, freedom from deficiencies, and categories. Agyapong, Acheampong, and Kwakye (2015) suggest that organisations have multiple images, hence, the university can use that picture as an important measure of perceived quality of service to its advantage in offering distance education to influence the company's customer expectations. Wu and Liang (2009) claim that for customers to be satisfied with a high quality of service, there should be a pleasant atmosphere and an entertaining experience at the place where the service is delivered. Berry, Parasuraman, and Zeithaml (1991) observe that service quality is a significant differentiator and the most effective strategic tool for organisations and Heskett et al., (1994) concluded that service quality drives customer satisfaction, which creates customer loyalty leading to growth.

One of the most important factors that influence the quality of distance education is the performance of the instructors in the delivery of lessons (Bolliger, 2004; Huynh, 2005; Ladyshewsky, 2013; Michael, Maithya, \& Cheloti, 2016). The nature of distance education requires instructors to exhibit a different set of skills and responsibilities. Instructors in distance education programmes serve as the mediator between the student and the study materials (Beaudoin, 1990), a situation different from face-to-face interactions in traditional education. As a result, the instructor must understand the increased diversity of learners and determine test formats, measurement practices, and assessment strategies accordingly (Banerjee \& Brinckerhoff, 2002) to persuade and motivate students to accept a distance learning environment (Selim, 2005). To ensure the high-quality performance of instructors in the distance learning programme, the UEW continuously organize capacity building programmes for its tutors to be able to offer quality face-to-face and online teaching. These programmes aimed to equip the tutors with the knowledge and needed resources to offer excellent education, as well as provide support for students. 


\section{- Packaging}

According to Hill (2005) when individual preferences become complex and diverse, the packaging is the major product branding strategy. Underwood (2003) echoes that package design with product images attracts consumers' attention to the brand. Rundh (2005) echoed the importance of packaging which attracts consumer's attention to the brands, improves identity, and affects the expectations of consumers about a particular product. Packaging is also important in the marketing environment and is one way to gain consumer notice in terms of goods and services (Berkowtiz, 1987). Wells, Farley, and Armstrong (2007) observe that packaging works as an instrument for differentiation, and a means to make consumers decide the product from a wide range of parallel products. Adelina and Morgan (2007) claim that packaging is one of the most important resources in marketing communications today and that packaging has a huge effect on consumers purchasing behaviour. Saeed, Lodhi, Mukhtar, Hussain, Mahmood, and Ahmad (2011) emphasise that organisations should integrate the brand image, brand attachment, and environmental effects to have an impact on consumer purchase decisions and that packaging also stimulates customer's buying behaviour (Wells, Farley, \& Armstrong, 2007).

Research has established a relationship between student satisfaction and how distance education programmes are packaged. For example, a positive relationship has been reported between the consistency and density of the learning content (Swan, 2001), flexibility and quality of the course (Pei-Chen, Tsai, Finger, Yueh-Yang et al., 2008), course structure (Eom, Wen, \& Ashill, 2006) and the students' satisfaction and perceived learning. The UEW strives to achieve these in terms of the delivery of learning content and the quality of course manuals. The UEW distance education programme has branded itself through the use of a variety of modes/channels to deliver learning content to students. The university uses a combination of face-to-face bi-weekly weekend tutorials at the Study Centres, interactive teaching and learning on Moodle Learning Management System, video conferencing via the Internet on tablets and seminars/presentations. Additionally, students are given course manuals that cover the entire contents of the courses to be treated in students' choice of programmes. These manuals are designed in an interactive manner so that students can feel the "presence of the teacher" as they read the module (Institute for Distance and e-Learning, UEW, 2020). 


\section{- Bonding}

Bonding is the close economic, psychological, emotional, and/or physiological attachment of members within an associative and collaborative relationship (Forgas et al. 2010). Developing a buyer-seller relationship is a critical bonding tool. It reduces emotional conflict relationship between players in a relationship (Palmatier, 2008; Sin et al., 2005). For the effective formation of bonding attitude, the social bond is important (Chiu, 2002). Social Bonds described as a personal tie that emphasises on service dimension in the buyer-seller relationship through interpersonal relations and exchanges to establish friendships (Berry, 1995; Wilson 1995). Social bonds positively influence customer's emotions toward feelings associated with service experience and have a major psychological benefit from a customer's point of view (Chiu, 2002). Social bonds include self-disclosure, listening, and caring for clients, which in effect strengthen the shared connection between the consumer and the service provider, their transparency, and their degree of proximity (Chiu, 2002). Damkuviene and Virvilaite (2007) argued that interdependence, long-term outlook, engagement, and trust should be the elements in the relationships. Kandampully and Duffy (1999) contend that a customer's interest in maintaining a loyal relationship is depended on the organisation's ability to anticipate customers' future needs and offering them before any other company.

A precursor of bonding between learners and instructors is the levels and amount of interactions that occur between them. An interactive teaching style and higher levels of learnerinstructor interaction serve as a good predictor of student satisfaction (Arbaugh, 2000; Kuo, Walker, Belland \& Schroder, 2013; Moore, 2002). For example, Swan (2001) found that most students who reported higher levels of interaction with instructors and peers report higher levels of satisfaction and higher levels of learning. UEW can ensure higher levels of learner-instructor interactions through the tutorials the distance education programme offers to students. Tutorials are organised bi-weekly on Saturdays, with the inclusion of Sundays during examinations. Tutors with a specialty in the various courses meet students during tutorials to discuss issues concerning their programmes, clarify difficult areas in the course and also give students the opportunity to ask questions that may be boggling their minds as they do their independent studies. The period is also used to counsel students, resolve issues, and give course materials to students. 


\section{- Customer satisfaction and loyalty}

Customer satisfaction is a widely researched field in marketing and has been the topic of numerous studies. Chavan and Ahmad (2013) see customer satisfaction as is a strategy adopted by companies to satisfy a customer's needs. It increases customer loyalty and, hence, sales and profits (Chavan \& Ahmad, 2013). Kotler (2000) considers it as customer attitude or behaviour towards the difference between what customers expect from the product and what they receive regarding fulfilment of a goal. Walsh et al. (2006) identify a strong relationship between customer satisfaction and the corporate reputation of an organisation. According to Wood (2008), effective marketing involves all aspects of an organisation and must consistently provide value to win customers and earn their loyalty. This involves the organisation creating benefits for customers to increase and maintain their repeat business (Anderson and Jacobsen 2000). All this agrees with claims that true consumer loyalty is generated when consumers become an organisation's advocate without any motivation (Oliver, 1997) and with the suggestion that greater customer satisfaction leads to greater customer intent to repurchase a product (Rust and Zahorik, 1993).

Anderson and Sullivian (1993) suggest that a high level of customer satisfaction decreases the perceived need to switch service providers. This increases customer repurchases of the organisation's product and leads to higher profitability in the long-run (Bowen \& Chen, 2001; Anderson et al., 1994; Jones \& Sasser, 1995; Reichheld, 1996). These studies all place a strong emphasis on the importance of service quality and the association between service quality and customer perception, customer satisfaction and customer loyalty all enhancing company competitiveness (Cronin \& Taylor, 1992; Taylor, \& Baker, 1994; Schulz, 2012; Parasuraman et al. 1988; Anderson and Sullivan, 1993; Dick and Basu, 1994) Several other studies support this idea that positive corporate and brand identity is a determinant of consumer loyalty (Gronroos, 1988; Anderson et al. 1994; Andreassen, 1999; Kotler and Armstrong, 2008; Kapiki, 2012). The UEW services and the corporate name has made the school one of the best in the Ghanaian distance education market. As the first institution to rollout a distance educational programme, the university has a niche in the educational market mainly due to the good corporate image the university has built and customer satisfaction through lecturer-student interaction which in the long-run lead to customer loyalty. 


\section{- Word-of-mouth (WOM) communication}

The provision of two-way communication for students to engage in dialogue with the DE institution is an attribute of distance education (Keegan,1996). WOM communication is interpersonal communication that affects the consumers' decision-making process about the purchase of goods and services (Mangold, Miller, \& Brockway,1999). Studies show that it has a higher effect on consumer product judgement than does print media (Herr, et al, 1991), and is often related to customers' satisfaction or dissatisfaction with previous purchase experiences. Therefore, for WOM communication to elicit a positive response from consumers, it must be vivid and useful to generate interest in consumer purchase patterns (Yu \& Tang (2010). In the educational setting, positive WOM communication by students on distance education programmes sells the university and its programme to the external world. Thus, true consumer loyalty is generated when consumers become an organisation's advocate without any motivation (Oliver,1997). This is the UEW experience.

WOM communication is a promotional tool for the UEW distance education programme. UEW's interaction with students has generated a positive word of mouth promotion for it in the educational market on the quality of the university's distance education programmes. The WOM communication by students broadcasts satisfaction with programme content, the commitment by lecturers to give their best effort, recognition of students by all academic and non-academic staff and effectively announces the university's use of a combination of face-to-face bi-weekly weekend tutorials and interactive teaching and learning on Moodle Learning Management System.

\section{Methodology}

Sample

One-hundred and twenty (120) students taking part in the UEW distance programme at the Kumasi Girls SHS Study Center were used for the study. To gather data, we approached students who had reported for classes for the distance education programme at the Kumasi Girls SHS Center. Participation was voluntary and anonymous. Based on the recommendations of Mooi and Sarstedt (2011), the sample size of 120 was deemed to be adequate for cluster analysis. Mooi and Sarstedt (2011), recommend that for a sample size to be sufficient for cluster analysis the number of observations should be at least $2^{\mathrm{m} ;}$ where $\mathbf{m}$ is the number of clustering variables. In this study, the number of clustering variables was four (service quality, social bonding, packaging, and price) 
suggesting that a sample size of 16 will be sufficient for the study. The sample size of 120 was, therefore, more than sufficient for the study.

\section{Measures}

Self-administered questionnaires were used to elicit responses regarding students' overall satisfaction with the UEW distance education programme. Respondents were expected to indicate the extent to which they agreed or disagreed with certain statements about satisfaction. These items were measured using a five-point, Likert scale with the following anchors: $1=$ Strongly Disagree, 2 = Disagree, 3 = Neutral, 4 = Agree, and 5 = Strongly Agree. We also collected data on two separate factors that are related to satisfaction (i.e. positive word of mouth and likelihood to recommend) about/the UEW distance education programme.

\section{Results}

Table 1: Descriptive statistics and correlation matrix for cluster variables

\begin{tabular}{llllllllll}
\hline Variable & N & Min. & Max. & Mean & SD & $\mathbf{1}$ & $\mathbf{2}$ & $\mathbf{3}$ & $\mathbf{4}$ \\
\hline 1. Service Quality & 120 & 2 & 10 & 7.28 & 2.08 & - & & & \\
2. Social Bonding & 120 & 1 & 5 & 3.71 & 1.34 & $.76^{*}$ & - & & \\
3. Packaging & 120 & 1 & 5 & 2.72 & 1.37 & $.58^{*}$ & $.46^{*}$ & - & \\
4. Price & 120 & 1 & 5 & 2.66 & 1.40 & $.74^{*}$ & $.63^{*}$ & $.76^{*}$ & -
\end{tabular}

Note $: \mathrm{SD}=$ Standard Deviation; Min. = Minimum; Max. $=$ Maximum; ${ }^{*} p<.01$

Table 1 contains the detail of the data collected on the variables of the study which involve service quality, social bonding, packaging, and price. From the 120 respondents that participated in the study, the minimum score was 1 whereas the maximum was 5. It was observed that these variables averaged $7.28,3.71,2.72$, and 2.66 respectively. Service quality obtained the highest mean with a corresponding standard deviation of 2.08. The correlation analysis in this study sought to establish the relationships between the variables to ascertain the existence of multicollinearity which talks about the extent to which a variable can be explained by another. This was essential because an increase in multicollinearity obscures the interpretation of the variate as it complicates the establishment of the effect of any single variable because of the interrelationships. Tables 1 shows a significant positive relationship exists between service quality and social bonding, packaging, and price with $.76, .58$, and .74 respectively. This establishes a moderate correlation among the 
variables of the study which explains that as service quality increases, it strengthens social bonding, packaging, and as well increases the price.

Hierarchical cluster analysis based on squared Euclidean distance using Ward's method was conducted to group respondents. The analysis yielded three groups. The F-values in Table 2 shows that the means of the three groups are significantly different in terms of the four factors that influence students' satisfaction with UEW's distance education programme. The k-means cluster analysis was then used to segment students into groups (see Table 3). The first cluster has 18 respondents and has relatively low means across all the factors that influence satisfaction with UEW's distance education programme. This shows that this segment should not be a likely target for UEW in its distance education programme.

The second cluster has 54 respondents. It is the largest cluster and is most distinguished by relatively higher means on service quality and price. The means for the other variables for this cluster are also relatively higher than the other clusters. Thus, this segment can be seen as highly satisfied with the UEW distance education programme and that UEW provides high-quality service at affordable prices in its distance education programme. The third cluster has 48 respondents. This cluster showed average mean scores across all the clusters. This indicates that this cluster is moderately satisfied with the UEW distance education programme.

Table 2

Means and One-Way ANOVA results from hierarchical cluster analysis

\begin{tabular}{|c|c|c|c|c|c|c|c|c|}
\hline \multirow[b]{2}{*}{ Variable } & \multicolumn{3}{|c|}{$\begin{array}{l}\text { Mean Values } \\
\text { Cluster Number }\end{array}$} & \multicolumn{5}{|c|}{$\begin{array}{l}\text { Mean-Centered Values } \\
\text { Cluster Number }\end{array}$} \\
\hline & 1 & 2 & 3 & 1 & 2 & 3 & $\boldsymbol{F}$ & Sig. \\
\hline Service Quality & 5.50 & 7.14 & 9.45 & -1.78 & -0.14 & 2.17 & 65.22 & .000 \\
\hline Social Bonding & 2.44 & 3.76 & 5.00 & -1.27 & 0.05 & 1.29 & 65.91 & .000 \\
\hline Packaging & 1.11 & 2.94 & 4.12 & -1.61 & 0.22 & 1.40 & 80.24 & .000 \\
\hline Price & 1.08 & 2.71 & 4.30 & -1.58 & 0.05 & 1.64 & 89.34 & .000 \\
\hline Cluster size $(N)$ & 36 & 51 & 33 & 36 & 51 & 33 & & \\
\hline
\end{tabular}


Table 3

Means and One-Way ANOVA results from k-means cluster analysis

\begin{tabular}{|c|c|c|c|c|c|c|c|c|}
\hline \multirow[b]{2}{*}{ Variable } & \multirow[b]{2}{*}{1} & \multicolumn{2}{|c|}{$\begin{array}{l}\text { Mean Values } \\
\text { Cluster Number }\end{array}$} & \multicolumn{4}{|c|}{$\begin{array}{l}\text { Mean-Centered Values } \\
\underline{\text { Cluster Number }}\end{array}$} & \multirow[b]{2}{*}{ Sig. } \\
\hline & & 2 & 3 & 1 & 2 & 3 & $F$ & \\
\hline Service Quality & 3.61 & 8.94 & 6.79 & -3.67 & 1.66 & -0.49 & 212.51 & .000 \\
\hline Social Bonding & 1.56 & 4.57 & 3.54 & -2.15 & 0.86 & -0.16 & 83.66 & .000 \\
\hline Packaging & 1.44 & 3.78 & 2.00 & -1.28 & 1.06 & -0.72 & 61.06 & .000 \\
\hline Price & 1.17 & 3.98 & 1.73 & -1.49 & 1.32 & -0.93 & 180.79 & .000 \\
\hline Cluster size $(N)$ & 18 & 54 & 48 & 18 & 54 & 48 & & \\
\hline
\end{tabular}

We further collected data on positive word of mouth and the likelihood to recommend UEW to test the validity of the cluster. The results (see Table 4) show that the overall MANOVA model is significant $(F=.203, \mathrm{df}=3, p=.000)$

\section{Table 4}

MANOVA results assessing cluster solution criterion validity

\begin{tabular}{lccccc}
\hline Variable & $\begin{array}{c}\text { Cluster } \\
\text { Number }\end{array}$ & $\begin{array}{c}\text { Cluster } \\
\text { Mean }\end{array}$ & $\begin{array}{l}\text { Multivariate F } \\
\text { (Wilks' Lambda) }\end{array}$ & Univariate F & p \\
\hline \multirow{2}{*}{ Positive word of mouth } & 1 & 1.59 & .203 & 70.091 & .000 \\
& 2 & 3.94 & & \\
Likelihood to recommend & 1 & 1.46 & 146.152 & .000 \\
& 3 & 2.38 & &
\end{tabular}

Note: Multivariate F has 3 degrees of freedom; Univariate F has 2 degrees of freedom

\section{Discussions and Conclusions}

Tables 2 and 3 above display the results of the hierarchical and non-hierarchical k-means cluster analysis using simple Euclidean distance as the similarity measure to conduct and specify a three- 
cluster solution and the initial cluster centres that were generated from the hierarchical cluster analysis. The three factors were drawn based on the results from the hierarchical cluster solutions to affect the non-hierarchical cluster. These clusters which are the segments as regards the study comprises of highly satisfied, moderately satisfied, and least satisfied. Hair et al. (2012) state cluster size and significance of clustering variable differences as the two distinguished differences between the hierarchical and non-hierarchical results. Comparing the results from the two solutions, non-hierarchical cluster sizes produced 18,54 , and 48 as against 36,51 , and 33 for the hierarchical and this is attributed to the fact that the non-hierarchical is able to redistribute observations among its clusters and also has the ability to demarcate clusters that are most distinctive than the hierarchical solutions.

Table 3 contains ANOVA results that project the variations among variable means across the three clusters. The results are expected to be statistically significant because the clusters were formed from the four-clustering variables (Hair et al., 2014). The F- values specify that all four variables are significantly different. Predominantly, service quality and price have very large Fvalues (of 212.51, and 180.79) respectively. The non-hierarchical results suggest that the cluster solution is satisfactorily discriminating observations.

The first cluster has 18 observations and is distinguished by relatively low means for social bonding, packaging, and price. The only exception is service quality, but it recorded the lowest among all the clusters. This implies that generally, the cluster is a representation of a market segment touted as underperforming. Where students are least satisfied mainly in social bonding, packaging, and price of the UEW distance education programme and the overall lower means suggest that this segment should not be considered as a probable target for the institution.

The second cluster has 54 observations and is distinguished by comparatively higher means on service quality and price. This is interpreted as a segment touted as one in which UEW scores highly satisfactory with its distance education programme by providing high-quality service at an affordable price. UEW will be right to conclude that the segment is as well favourable for other variables like social bonding and packaging because they have higher means compared to all other segments, and it is the highest segment by far.

The final cluster has 48 observations and is distinguished by a higher mean for service quality. However, it falls behind cluster 2 in the pecking order in terms of the high means but 
comes before cluster 1 and for that reason automatically positioned the average segment. This implies that students from this cluster are satisfied with the quality of the UEW distance education programme but are not happy with the packaging and the tuition fees charged. Bonding becomes somewhat difficult, and for that reason, the segment is a moderately satisfied one. Nonetheless, UEW can improve service quality and other variables to turn the tables.

Table 4 estimates a MANOVA model using two criterion validity variables as the dependent and cluster segment membership as the independent variables. This was done because a correlation was established among the dependent variables (Hair et al., 2014). The criterion variables in this case were the positive word of mouth and the likelihood to recommend UEW to test the validity of the cluster. The overall effect was significant at $(F=.203, \mathrm{df}=3, p=.000)$ which provides grounds for the variables to be predicted by knowing which segment a student belongs to. The individual F-values were all significant and they validated the findings ( $\mathrm{F}=70.091$, $146.152 ; \mathrm{p}=0.000,0.000$ ) for positive word of mouth and likely to recommend respectively.

The current study classified 120 students of the UEW distance learning based on the preferences that influence their choice of distance education in Ghana. Respondents were segmented into three clusters that comprised of highly, moderately, and least satisfied based on four preferences (price, quality, packaging, and social bonding) that influenced their satisfaction with the distance education programme of UEW. In all, 18 of the respondents were in the segment of least satisfied, 54 were highly satisfied, and 48 were in the segment of moderately satisfied. In addition to differences in the mean values of the clustering variables, there were statistically significant differences between the groups in terms of positive word of mouth and likely to recommend UEW to others.

The results from the study observed both differences and similarities in customer satisfaction among the three segments. The findings ranked cluster two as the highest among the three. It made 54 observations and is distinguished by comparatively higher means on service quality and price. Meanwhile, all the other variables recorded higher means in this segment that exceeded all the other segments implying that UEW highly satisfies the segment with its distance education programme by providing affordable high-quality services. The results are in line with the argument of Heskett et al., (1994) that service quality drives customer satisfaction which in turn creates customer loyalty leading to growth. Additionally, the quality of the service serves as 
a key predictor of customer satisfaction because it is positioned between the continuum of customer's expectations and the actual perception of the service performance (Bitner et al., 1990; Parasuraman et al., 1985). In such instances, customers employ price in their evaluation and judgement of product and service quality of which availability and affordability are central for the price to be considered as reasonable (Wang, 2006; Kotler \& Keller, 2009). Importantly, the attitude of the students in this segment demonstrates that the perception of a customer is for the price charged to match the quality delivered (Oliver, 1997).

The findings of the study also revealed that Cluster 3 which represented the moderately satisfied segment emerged closely after Cluster 2 with 48 respondents. Service quality among the other variables recorded a higher mean value less than that of Cluster 2 but greater than Cluster 1 and the remaining variables were marginally differentiated among members of the segment. This implies that UEW satisfies this segment moderately with moderate prices and a moderation impact of packaging and social bonding. This is in line with previous postulations from researchers that when a customer perceives the fairness of the price given by the service provider, it develops positive feelings toward the service provider gradually which in turn evolved into a behavioural intention (Yieh et al., 2007) and the satisfaction of the customer due to value placed on the service received (Lenka et al., 2009; Kaura \& Datta, 2012). This segment is placed at the mid-point of the continuum where members are neither satisfied nor dissatisfied with the distance education programme that UEW delivers. The institution can employ some business strategies to target this segment to convert them into profitable customers in the future.

Finally, the last cluster realised 18 respondents who have the least satisfaction as regards the services of the UEW distance education programme. The members had similarities among all the other variables (social bonding, packaging, and price) with service quality as the only exception. Although service quality was differentiated among the other variables, it was the least of all the segments. This segment was the least among the three and the implication is that the members are the least satisfied with all the offerings of UEW and for that reason targeting it for future growth will be a misplaced priority.

Our findings further reveal that the strongest relationships among the variables existed between service quality, price and customer satisfaction. This affirms prior studies which argue that service quality dimensions have a positive impact on customer satisfaction except for 
tangibility (Lenka et al., 2009; Kaura \& Datta, 2012; Kapiki, 2012; see also, Kaura, 2013 who made a similar observation in the banking sector; Walsh et al., 2006; and Wood, 2008).

The findings further confirm price as a factor that significantly influences customer satisfaction particularly in the service industry (Singh \& Sirdeshmukh, 2000; Jiang \& Rosenbloom, 2005; Han \& Ryu, 2009). Nonetheless, the success of price effects hinges on the perception of the customer regarding value creation and fairness of price that produces positive behaviour toward future actions (Yieh et al., 2007; Kaura, 2013). Although packaging and social bonding were among the variables of the study, they had minimal impact on the students across all the segments.

Finally, the respondents varied significantly among the various segments as regard positive word of mouth and likelihood to recommend UEW distance learning to others and the results are consistent with the argument of Brown, Barry, Dacin, and Gunst (2005) that positive word of mouth accompanied by recommendation are bye products of customer satisfaction, commitment, and recognition that usually occur from a previous experience (Wilson \& Peterson, 1989). Additionally, word of mouth communication influences the decision-making process of consumers in their purchases because the information from colleagues is deemed as much more credible than that of the organisation (Mangold, Miller, \& Brockway, 1999).

In conclusion, we argue that UEW must take advantage of the significant impact of service quality and price factors on customer satisfaction that runs through all the segments to develop and implement strategic decisions to achieve a competitive advantage in the distance education market.

\section{Limitations and Future Research}

We like to draw attention to some limitations of the study. First, the study did not include all variables potentially related to students' satisfaction in distance education, although it covered all the variables of interest in this particular context. Further research can look at other variables that influence students' satisfaction (e.g. corporate image, reputation, learning environment). This will help provide a more holistic view and understanding of student satisfaction. Second, this study focused on only one study century, the Kumasi Girls Study Center in Ghana. Future researchers who are interested in students' satisfaction with distance learning education might include other study centers to increase the sample size and broaden the scope of the study. Finally, the study did not explore the potential role of lecturers in students' satisfaction in distance education. Future studies might bring new light to this matter by looking at lecturers' role in students' satisfaction. 


\section{References}

Adelina, B \& Morgan, H (2007). Consumer buying behaviour and perception toward retail brand baby products. Journal of Brand Management, 8 (3).

Agwu, M. E., Carter, A. L., \& Murray, P. J. (2014). Downsizing as a strategic tool for effective organizational management: A case study of Nigerian banks. International Journal of Research in Management, Science \& Technology, 2(1), 1-9.

Agyapong, K., Acheampong, A., \& Kwakye, B. M. (2015). Price as a motivating factor for students' enrolment: Distance learning perspective. The International Journal of Business \& Management, 3(2), 33-38

Al Khattab, S. A., \& Aldehayyat, J. S. (2011). Perceptions of service quality in Jordanian hotels. International Journal of Business and Management, 6(7), 226.

Anderson, E. W., \& Sullivan, M. W. (1993). The antecedents and consequences of customer satisfaction for firms. Mark. Sci., 12, 125-143.

Anderson, H., \& Jacobsen P. N. (2000). Creating Loyalty: Its Strategic Importance in Your Customer Strategy. In S. A. Brown (ed.), Customer Relationship Management. Ontario: John Wiley.

Anderson, E.W. (1994). Variation in Customer Satisfaction and Retention. Marketing Letters, 5 (1).19- 30 .

Anderson, E.W., \& Sullivan, M.W., (1993). The antecedents and consequences of customer satisfaction firms. Marketing Science, 12(2), 241-268

Anderson, E.W., Fornell, C., \& Lehmann, D.R., (1994). Customer satisfaction, market share, and profitability; findings from Sweden. Journal of Marketing, 58, 53-66

Anderson, H., \& Jacobsen P. N. (2000). Creating Loyalty: Its Strategic Importance in Your Customer Strategy. In S. A. Brown (ed.), Customer Relationship Management. Ontario: John Wiley.

Anderson, S., Klein, L., \& Widener, S.K. (2008). Drivers of Service Satisfaction: Linking Customer Satisfaction to the Service Concept and Customer Characteristics. Journal of Service Research, 10(4), 365-381. 
Andreason, A. R. \& Kotler, P. (2003). Strategic marketing for Nonprofit Organisations, (6 ${ }^{\text {th }}$ ed.), Upper Saddle River, NJ: Prentice-Hall.

Andreassen, T.W., (1999). What Drives Customer Loyalty with Complaint Resolution? Journal of Service Research, 1(4), 324-332

Anthanassopoulos, A., Gounaris, S., \& Sathakopoulos, V. (2001). Behavioral responses to customer satisfaction: an empirical study. European Journal of Marketing, 35(5/6), 687-707

Anton, J. (1996). Customer Relationship Management, New Jersey: Prentice-Hall Inc.

Bagram, M.M.M. \& Khan, S. (2012). Attaining consumer loyalty: The role of consumer attitude and consumer behaviour. International Review of Management and Business Research 1(1), $1-8$.

Bearden, B., Ingram, T. \& Larfforge, B. (2004). Marketing Principles and Perspective. New York, NY: McGraw Hill Companies.

Berkowitz, M. (1987). Product shape as a design innovation strategy. Journal of Product Innovation Management: An International Publication of the Product Development \& Management Association, 4(4), 274-283.

Berry, L.L. (1995). Relationship marketing of services - growing interest, emerging perspectives. Journal of the Academy of Marketing Science, 23(4), 236-45.

Berry, L. \& Parasuraman, A. (1991), Marketing Services: Competing through Quality. New York, NY : The Free Press.

Bitner, M., Booms, B. \& Tetreault, M. (1990). The Service Encounter: Diagnosing Favourable and Unfavourable Incidents. Journal of Marketing, 54, 71-84.

Bolton, R. N., \& Drew, J. H. (1992). Mitigating the effect of service encounters. Marketing Letters, $3(1), 57-70$.

Bowen, J. T., \& Chen, S. L. (2001). The Relationship between Customer Loyalty and Customer Satisfaction. International Journal of Contemporary Hospitality Management, 213-217.

Brown, T. J., Barry, T. E., Dacin, P. A., \& Gunst, R. F. (2005). Spreading the word: Investigating antecedents of consumers' positive word-of mouth intentions and behaviours in a retailing context. Journal of the Academy of Marketing Science, 33, 123-138

AJOTE Vol. 10. No.1 (2021), 365-391 
Chavan, J., \& Ahmad, F. (2013). Factors affecting on customer satisfaction in retail banking: An Empirical Study. International Journal of Business and Management Invention, 2(1), 55-62.

Chiu, C. H. A. (2002). Study on the cognitive and affective components of service quality. Total Quality Management, 13(2), 265-274.

Cronin, J. J., \& Taylor, S. A. (1992). Measuring service quality: a re-examination and extension. Journal of Marketing, 56, 55-68.

Cronin, J., \& Morris, M. (1989). Satisfying customer expectations: The effect on conflict and repurchase intentions in industrial marketing channels. Journal of Academy of Marketing Science, 17(1), 41- 49.

Damkuviene, M. \& Virvilaite, R. (2007). The concept of relationship marketing theory: Definitions and theoretical approach. Economics and Management, 12, 318-325

De Lourdes Machado, M., Brites, R., Magalhães, A., \& Sá, M. (2011). Satisfaction with Higher Education: critical data for student development. European Journal of Education, 46(3), 415-432.

Dick, A.S., \& Basu, K., (1994). Customer Loyalty: towards an integrated conceptual framework, Journal of the Academy of Marketing Science, 22, 99-113

Dolnicar, S. (2002). A review of data-driven market segmentation in tourism. Journal of Travel \& Tourism Marketing, 12(1), 1-22.

Doyle, D. P. (2004). Don't France me in Fragmented markets for Technology and patent acquisition strategic of firms. Journal of management science, 50(6)

Durling, D., Cross, N., \& Johnson, J. (1996). CAI with style. Paper presented at the $18^{\text {th }}$ Annual Design Conference-Computer-aided Design Education. University of Bristol, England.

Evans, J. R., \& Lindsay, W. M. (1996). The management and control of quality, (3 ${ }^{\text {rd }}$ ed.). St. Paul: West Publishing Company.

Fornell C. (1992). A national satisfaction barometer: The Swedish Experience. Journal of Marketing, 56, 6-21.

Forgas, S., Moliner, M.A., Sánchez, J. \& Palau, R. (2010). Antecedents of airline passenger 
loyalty: Low-cost versus traditional airlines. Journal of Air Transport Management, 16(4), $229-233$.

Garrison, R. (2000). Theoretical challenges for distance education in the $21^{\text {st }}$ century: A shift from structural to transactional issues. International Review of Research in Open, Open and Distance Learning 1(1).

Gibbons, C. (2012). Stress, Positive Psychology and the National Student Survey. Psychology

Teaching Review, 18(2), 22-30.

Gronroos, C., (1988). Service quality: the six criteria of good perceived service quality, Review of Business, (9), 10-13

Gunter, B. \& Furnham, A. (1992). Consumer profiles: An introduction to psychographics. London: Routledge.

Han, H. \& Ryu, K. (2009). The Roles of the Physical Environment, Price Perception, and Customer Satisfaction in Determining Customer Loyalty in the Restaurant Industry. Journal of Hospitality and Tourism Research, (33)4, 487-510.

Herr, L. J. (1991). Relationship of binucleate Rhizoctonia isolates used for biocontrol of Rhizoctonia crown rot of sugar beet to anastomosis systems. Canadian journal of microbiology, 37(5), 339-344.

Hennig-Thurau T., Gwinner K.P. \& Gremler, D. (2002). Understanding relationship marketing outcomes: An integration of relational benefits and relationship quality. Journal of Service Research, 5(2), 230-47

Heskett, J. L.; Jones, T.; Loveman, G.; Sasser, W., \& Schlesinger, L. (1994). Putting the service profit chain to work. Harvard Business Review, 105-111

Hill, M., Tachedjian, G., \& Mak, J. (2005). The packaging and maturation of the HIV-1 Pol proteins. Current HIV research, 3(1), 73-85.

Hinterhuber, A. (2008). Customer value-based pricing strategies: why companies resist. Journal of business strategy, 29(4), 41-50. 
Innis, D. \& La Londe, B. (1994). Customer service: The key to customer satisfaction, customer loyalty, and market share. Journal of Business Logistics, 15(1), 1-27

Gilbert, D.C. \& Jackaria, N. (2002). The efficacy of sales promotions in UK supermarkets: a consumer view. International Journal of Retail \& Distribution Management, 30(6), 315322. https://doi.org/10.1108/09590550210429522.

Jiang, P. \& Rosenbloom, B. (2005). Customer intention to return online: price perception attribution-level performance, and satisfaction unfolding over time. European Journal of Marketing,39 (1), 150-174.

Johnson, M.D., \& Fornell. C. (1991). A framework for comparing customer satisfaction across individuals and product categories. Journal of Economic Psychology, 12(2), 267-286.

Jones, T. \& Sasser, W. (1995). Why Satisfied Customers Defect? Harvard Business Review, 73 (6), 88-99.

Kandampully, J., \& Duffy, R. (1999). Competitive advantage through anticipation, innovation and relationships. Management Decision, 37(1), 51-56.

Kapiki, S. T. (2012). Current and future trends in tourism and hospitality. The case of Greece. International Journal of Economic Practice and Theories, 2(1).

Kaufman, R., Watkins, R. \& Guerra, I. (2001). The future of distance learning: Defining and sustaining useful results. Education Technology, 41(3), $19-26$.

Kaura, V. (2013). Antecedents of customer satisfaction: a study of Indian public and private sector banks. International Journal of Bank Marketing, 31(3), 167- 186.

Kaura, V. (2013). Service Convenience, Customer Satisfaction, and Customer Loyalty: Study of Indian Commercial Banks. Journal of Global Marketing, 26(1), 18-27.

Kaura, V. \& Datta, S. K. (2012). Impact of Service Quality on Satisfaction in the Indian Banking Sector. The IUP Journal of Marketing Management, 11(3), 38-47.

Keaveney, M. S. (1995). Customer switching behaviour in service industries: an exploratory study. Journal of Marketing, 59(2), 71-82.

Keegan, D. (1996). Foundations of distance education, (3rd ed.) London: Routledge. 
Kolter, P. (2000). Marketing Management, (10th ed.), New Jersey: Prentice-Hall

Kotler, P., \& Armstrong, G. (2008). Principles of marketing, (12th ed.), Upper Saddle River,

N.J.: Pearson Prentice Hall.

Kotler, P., Armstrong, G., Saunders, J., \& Wong, V. (2002). Principles of Marketing, (3rd European ed.). London: Prentice-Hall.

Kotler, P., Bowen, J., \& Makens, J. (1996). Marketing for hospitality and tourism. USA: PrenticeHall Incorporation

Kuo, Y., Walker, A.E., Belland, B.R., \& Schroder, K.E.E. (2013). A Predictive Study of Student Satisfaction in Online Education Programs. International Review of Research in Open and Distance Learning, 14(1), 16-39.

Kurtenbach, J. (2000). Focusing on customer service. Health Forum Journal, 43(5), 35-37.

Lenka, U., Suar, D. \& Mohapatra, P. K. J. (2009). Service Quality, Customer Satisfaction, and Customer Loyalty in Indian Commercial Banks. Journal of Entrepreneurship, 18(1), 4764.

Levesque, T \& McDougall, H. G. (1996). Determinants of customer satisfaction in retail banking. International Journal of Bank Marketing, 14(7), 12-20.

Mangold, W. G., Miller, F., \& Brockway, G. R. (1999). Word-of-mouth communication in the service marketplace. Journal of services Marketing.

Mankoe, J.O. (2006). Policy analysis in education. Kumasi: Payless Publication Ltd.

Manu, Y. I, \& Agyapong, K. (2014). Prospects of providing distance education programmes for professional teachers in Ghana: A case of UEW, Winneba study centre. International Journal of Education and Research, Vol. 2, No.10, 593-600.

Matzler, K., Renzl, B. \& Faullant, R. (2007). Dimensions of price satisfaction: a replication and extension. International Journal of Bank Marketing, 25(6), 394-405

Mooi, E., \& Sarstedt, M., (2011). A Concise Guide to Market Research. Springer Berlin Heidelberg: DOI 10.1007/978-3-642-12541-6_9 
Moore, M. G. (1989). Editorial: Three types of interaction. The American Journal of Distance Education, 3(2), 1-6.

Mylonakis, J. (2009). Bank satisfaction factors and loyalty: A survey of the Greek bank customers. Innovative Marketing, 5(1)

Nelson, E., Rust, R.T., Zahorik, A., Rose, R.L., Batalden, P. \& Siemanski, B. (1992). Do patient perceptions of quality relate to hospital financial performance?". Journal of Healthcare Marketing, 1-13.

Oliva, T. A.; Oliver, R. L. \& MacMillan, I. C. (1992). A catastrophe model for developing service satisfaction strategies. Journal of Marketing, 56(3), 83-95

Oliver, L. R. (1999). When consumer loyalty? Journal of Marketing, 33-44.

Oliver, R. L. (1997). Satisfaction: A Behavioural Perspective on the Consumer. New York: McGraw Hill

Palmatier, R.W. (2008). "Interfirm relational drivers of customer value”, Journal of Marketing, Vol. 72, pp. 76-89.

Parasuraman, A., Zeithaml, V. A., \& Berry, L.L., (1988). SERVQUAL: a multiple-item scale for measuring customer perceptions of service quality. Journal of Retailing, 64, (1), 12-40

Peng, L. Y., \& Wang, Q. (2006). Impact of relationship marketing tactics (RMTs) onswitchers and stayers in a competitive service industry. Journal of Marketing Management, 22 (1-2), 2559.

Perraton, H. (1988). A theory for distance education. In D. Sewart, D. Keegan and B. Holmberg (eds) Distance education: International perspectives (34-45), London: Routledge.

Perraton, H. (2004). Aims and purpose. In H. Perraton and H. Lentell (eds) Policy for open and distance learning; World review of open and distance learning, 2, 9-41, London: Routledge Falmer.

Pickton, D. \& Broderick, A. (2005). Identifying target audiences and profiling target markets. Integrated marketing communications, (2nd ed.). 
Reichheld, F. F., (1996). The Loyalty Effect. Boston, Massachusetts.: Harvard Business School Press.

Rundh, B. (2005). The multi-faceted dimension of packaging. British food journal.

Rust, R. T., \& Zahorik, A. J. (1993). Customer satisfaction, customer retention, and market share. J. Retail. Summer, 69, 193-215

Saeed, R., Lodhi, R.N., Mukhtar, A.M.J., Hussain, S., Mahmood, Z., \& Ahmad, M. (2011). Factors affecting consumer purchase decision in clothing industry of sahiwal, Pakistan. World Applied Sciences Journal, 24 (7): 844-849.

Salami, A. O., \& Adewoye, J. O. (2006). The Efficacy of market segmentation strategy in Nigerian Manufacturing Industries: A case study of Nigerian Bottling company, Ilorin, Nigeria. GeoStudies Forum. An International Journal of Environmental and Policy Issues, 3(1), 91-101.

Schulz R.N. (2012). The effects of business image on customer retention in hotels in Eldoret. European Journal of Business and Management, 4(18).

Sherry, A. C. (2003). Quality and its measurement in distance education implementation. In M.G. Moore \& W.G. Anderson (Eds.), Handbook of distance education (pp. 436-460). New Jersey: Lawrence Erlbaum Associates, Inc.

Sin, L., Tse, A., Yau, O., Chow, R., Lee, J. \& Lau, L. (2005). "Relationship marketing orientation: scale development and cross-cultural validation", Journal of Business Research, Vol. 58, pp. 185-94.

Singh, J. \& Sirdeshmukh, D. (2000). Agency and trust mechanisms in consumer satisfaction and loyalty judgments. Journal of the Academy of Marketing Science, 28(1),150-167.

Singh, J., \& Kaur, G. (2011). Customer satisfaction and universal banks: an empirical study. International Journal of Commerce and Management, 21 (4), 327-348.

Siu, N. Y. M., \& Chow, D. K. H. (2004). Service Quality in Grocery Retailing. Journal of International Consumer Marketing, 16(1), 71-87. doi:10.1300/j046v16n01_05

Sivadass, E., \& Baker-Prewitt, J. L. (2000). An examination of the relationship between service quality, customer satisfaction, and store loyalty. International Journal of Retail and Distribution Management, 28 (2), 73-82 
Spreng, R.A. \& Mackey, R.D. (1996). An empirical examination of a model of perceived service quality and satisfaction. Journal of Retailing, 72, 201-214.

Stafford, J.E. (1966). Effects of group influence on consumer brand preferences. Journal of Marketing Research, 3(1), 68-75

Straub, D., Boudreau, M. C., \& Gefen, D. (2004). Validation guidelines for IS Positivist Research. Communications of the AIS (13:24), 380-427.

Sujatha, K. (2002). Distance education at secondary level in India: The national open school. United Nations Educational, Scientific and Cultural Organization (UNESCO).

Tabachnick, B. G, \& Fidell, L. S. (2007). Using multivariate statistics, (5 ${ }^{\text {th }}$ ed.), USA: Pearson Education Inc.

Taylor, S. A., \& Baker, T. L. (1994). An assessment of the relationship between service quality and customer satisfaction in the formation of consumers ${ }^{\text {ee }}$ purchase intentions. Journal of Retailing, 70(2), 163-178.

Underwood, R. L. (2003). The communicative power of product packaging: creating brand identity via lived and mediated experience. Journal of marketing theory and practice, 11(1), 62-76

Varki, S. \& Colgate, M. (2001). The role of price perceptions in an integrated model of behavioural intentions. Journal of Services Research, 3(2): 232-240

Walkers, O. C. Jr., Boyd, H. W. Jr., \& Larreche, (1996). Marketing strategy Planning and implementation, (2 $2^{\text {nd }}$ ed.). Irwin.

Walsh G., Dinnie K. \& Wiedmann K.P. (2006). How do corporate reputation and customer satisfaction impact customer defection? A study of Private Energy Customers in Germany". Journal of Services Marketing, 20(6), 412-420.

Wang, F. K. (2006). Quality evaluation of a manufactured product with multiple characteristics. Quality and reliability engineering international, 22(2), 225-236.

Wells, L.E., Farley, H., \& Armstrong, G. A. J-C (2007). The importance of packaging design for own-label food brands. International Journal of Retail and Distribution Management, 35 (9), 677-690. 
Wilson, D.T. (1995). “An integrated model of buyer-seller relationships", Journal of the Academy of Marketing Science, Vol. 23 No. 4, pp. 335-45

Wilson, W. R., \& Peterson, R. A. (1989). Some limits on the potency of word-of-mouth information. ACR North American Advances.

Wood, B. M. (2008). The marketing plan handbook, (3 ${ }^{\text {rd }}$ ed.), New Jersey: Pearson Education Inc.

Wu, C.H.-J. \& Liang, R.-D. (2009). Effect of experiential value on customer satisfaction with service encounters in luxury-hotel restaurants. International Journal of Hospitality Management, 28(4), 586-93.

Yieh, K., Chiao, Y. \& Chiu, Y. (2007). Understanding the Antecedents to Customer Loyalty by Applying Structural Equation Modelling. Total Quality Management, 18(3), 267-284.

Young, A. \& Norgard, C. (2006). Assessing the quality of online courses from the students' perspective. Internet and Higher Education, 9, 107-115.

Yu, C., \& Tang, X. (2010). The Construct and Influence of Word of Mouth: Receiver Perspectives. Journal of Chinese Marketing, 3, 13-18.

Zeithaml V.A. (2000). Service quality, profitability, and the economic worth of customers: What we know and what we need to learn. Journal of the Academy of Marketing Science, 28(1), pp. 67-81.

Zeithaml, V. A., Berry, L. L., \& Parasuraman, A. (1996). The behavioural consequences of service quality. Journal of Marketing, 60(2), 31-46.

Zeithaml, Valerie A. \& Bitner, Mary J. (2000). Services Marketing: Integrating customer focus across the firm, ( $2^{\text {nd }}$ ed.), Boston, M.A: Irwin/ McGraw-Hill

\section{Author contribution}

- Francis Owusu Mensah: introduction, literature review, discussion, and conclusion.

○ Kingsley Agyapong: literature review, methodology, discussion, and conclusion.

○ Augustine Acheampong: data analysis, discussion, and conclusion. 